\title{
The Role of Nuclear Weapons in NATO's Early Cold War Strategies (1949-1957)
}

\author{
KISS Petra ${ }^{1}$
}

\begin{abstract}
Since August 1945 atomic weapons have become significant factors in international relations, every state with great ambitions has aspired to get atomic secrets. The primary goal of the North Atlantic Treaty Organization (NATO) created in 1949 was - possessing the United States', a nuclear power's, security guarantee - to deter the Soviet agression. The first strategic documents of the Alliance were written with this very purpose. However, in the 1950s there was a shift in the allied nations' policies, which influenced NATO's strategic thinking as well, so in 1957 a real different strategic concept was adopted. Gaining technological superiority became the most important goal, which led to development and intense production of nuclear weapons. This article examines the emerging role of nuclear weapons and the changing strategy of the Alliance between 1949 and 1957.
\end{abstract}

Keywords: NATO, strategic concept, nuclear weapons, deterrence, massive retaliation, Cold War

\section{Introduction}

In a classic sense a strategic document takes into consideration - be it a state's or an alliance's strategy - a nation's total resources, its capabilities and constraints, and its traditions, culture and values. If there are significant changes in these factors, similar re-orientation is usually due to happen in the strategic thinking as well.

With the appearance of nuclear weapons (1945) the nature of warfare has been altered, its characteristics have been shifted. These weapons have such an enormous destructive power, which mankind has never seen before. The definition of victory and defeat were challenged, for neither politics nor the armed forces were prepared. [1] This urged NATO members and the whole Alliance to set out new directions. However, these changes raised many questions for the member states' leaders and for the military.

According to Lawrence Freedman, a British security policy expert, nuclear strategy is the strategy of the non-use of nuclear weapons. Atomic weapons and their (non)use has always belonged to the scope of highest political decision makers and - in contrast to any other weapon systems - not in the least has depended on the decision of soldiers or armed forces. [2]

The issue of using nuclear weapons was much more cardinal during the cold war than in the last two decades, nonetheless it has been a sensitive question of international relations

1 Ph.D. student at the Doctoral School of Military Sciences, National University of Public Service, Hungary, E-mail: kiss.petra@uni-nke.hu 
in our days, too. ${ }^{2}$ The best evidence for that is the "Special Advisory and Consultative Arms Control, Disarmament and Non-Proliferation Committee” which was established in 2013. The committee's primary task is to enhance the dialogue between NATO and Russia on confidence building and transparency regarding tactical nuclear weapons.

In 2014 NATO celebrated its $65^{\text {th }}$ anniversary which gave researchers an exquisite opportunity to interpret the North-Atlantic Organization's past again, study its presence and to envision its future. This paper is examining the Alliance's strategic documents from 1949 to 1957, with special regard to use of nuclear weapons. It also surveys the United States' changing guidelines, inasmuch as they had crucial influence on the Alliance's strategic thinking.

\section{The Atomic Secrets - the Foundation Stone of Western Defence}

The United States, after the invention and initial use of nuclear weapons in 1945, had a monopoly in this field for years. However, the role of these weapons - from a political and also from a military point of view - was to clarify even more years later. Atomic weapons got into focus of defence planning and strategy development in 1948 as an effect of the Berlin Crisis, but this time - more than 3 years after the first use of nuclear weapons - there was a huge uncertainty in the official documents: ${ }^{3}$

“...It appears imprudent either to prescribe or to prohibit beforehand the use of any particular weapons when the character of future conflict is subject only to imperfect prediction. [...] In the light of the foregoing, no action should be taken at the present time:

a) To obtain a decision either to use or not to use atomic weapons in any possible future conflict;

b) To obtain a decision as to the time and circumstances under which atomic weapons might or might not be employed." [4]

It was not for a moment called in question that the USA will ever give up the advantage nuclear weapons meant. ${ }^{4}$ In the same document it was also declared that Western-Europe's security is ensured by atomic weapons under American trusteeship, as only such devastating instruments can counterbalance the permanent Soviet military threat.

The United States' leaders realized that its monopoly can not be maintained for a long time. In August 1949 the Soviet Union carried out its nuclear tests. At that time optimistic British and American experts predicted the birth of the first Soviet atomic bomb at the end of the 1950s, the pessimistic opinions said it will take only 3-4 years for the Soviets to eliminate

2 Three NATO member states possess nuclear weapons: the United States since 1945, United Kingdom since 1952 and France since 1960 (however France has never offered these for Alliance use).

3 Similar "chaos" prevailed in war planning. American air force and navy commanders both counted on using nuclear weapons in support of their own battles, so the same targets were selected more times in war plans. In the Far East and Europe there were over 100 targets selected two times but in many cases this "overplanning" happenned even by three commanders. See more: [3].

4 In 1946 the United States presented its proposal for the United Nations Atomic Energy Comission. (The concept was named Baruch Plan after Bernard M. Baruch, who had an essential part in the development of this document and who served as a presidential advisor to three US Presidents.) According to the plan the USA would prefer the creation of a new international authority which would control the technology, supplies of raw materials and use of atomic energy. This authority's decisions would have been mandatory for every state, however the USA would have had a leading role in the organization. The initiative would have sorely harmed the countries' sovereignity and even more the Soviet Union's interests which would have never accepted American control of production so it rejected the proposal directly. See more: [5]. The Baruch Plan (Presented to the United Nations Atomic Energy Commission, June 14, 1946) and [6]. 
technical problems. The United States envisaged the appearance of a technology endangering the American homeland in only two decades. [2]

At that point presumably neither the USA nor the Soviet Union planned a war against the other party, but the Truman administration was seriously afraid that Soviet provocations, miscalculation and misconstruction of Western intentions may lead to a military conflict which could drive the world towards the Third World War. [7] This concern is reflected in the Alliance's strategies til the end of the Cold War.

"To win one hundred victories in one hundred battles is not the acme of skill. To subdue the enemy without fighting is the acme of skill." (Sun Tzu)

\section{Nuclear Weapons in Security Theories}

Thinking about nuclear weapons and their role in science appeared first of course in the USA. Many theories and approaches came out which reflected the same discrepancies as there were in the reality. Although the author refers to Soviet sources as well in order to substantiate the topic scientifically, these sources are primarily of political and military nature, we can not find any writings in Political Science or Security Theory such as in the USA or UK.

The precedent of the two Japanese cities which suffered nuclear attacks in 1945 proved unambiguously that the nature of warfare had been altered, its characteristics had shifted. ${ }^{5}$ The schools of thought were forced to re-think their view of war. The Clausewitzian thinking which goes back to the $19^{\text {th }}$ century describes war as the continuation of politics by other means. But this idea seemed to dissolve since in case of nuclear power politics controls these weapons - politics defines not only the goals for the armed forces but also how they have to fight in a war.

In the accelerating pace of development and production of atomic weapons the elementary question was: why do countries aim to get atomic secrets? How do the spread of nuclear weapons influence international security and what are the consequences?

Kenneth N. Waltz (1924-2013), an American neorealist political scientist argued that there are positive impacts for the international community if more states possess atomic weapons. In his opinion possessing nuclear weapons can not change the relations among states since these are the consequences of complex historical, economic, political and military factors. Examining the countries' motivation to get nuclear weapons Waltz listed seven reasons: [9]

- Great powers always aimed to defeat other significant powers and to develop more effective weapons. It is not surprising that the state which develops its own atomic bombs can expect such success.

- Certain states may worry because of the lack of nuclear weapons even if their allies have atomic secrets. They can never be sure that the nuclear ally is ready to help them in case of agression. So they are going to start their own nuclear program.

5 In Hiroshima ca. 60-80,000 people were killed instantly but many more died because of the long term effects of radiation sickness. More than $10 \mathrm{~km}^{2}$ of the city were destroyed through the explosion and because of the heat; there were fires throughout the city for months. The bomb that was dropped on Hiroshima was named "Little Boy" and had a mass of 4,000 kg and was about a 16 kilotons of TNT equivalent in explosive force. A few days later a bigger atomic bomb was dropped on Nagasaki by the American Air Force, it was named "Fat Man” and weighed more than 4,600 kg with 22 kilotons explosive force. One third of the city was destroyed and 40,000 people were killed instantly. See more: [8]. 
- If neither the state nor its allies possess nuclear wepons but their adversaries do, the state might begin nuclear developments.

- If a state is afraid of present or future large scale conventional conflicts, that can provoke similar aims to get atomic weapons.

- The reason may be that the state is not able or willing to get into a conventional arms race. In order to increase its security nuclear weapons are a much more effective and secure alternative.

- States also can aspire to have atomic weapons because of agressive intentions.

- At last there is an element which can be a reason or a result as well: possessing nuclear weapons increases the state's prestige and position in the international community.

In Waltz's concept the Clausewitzian cost-benefit theory is at work, simply modified and inversely. According to Clausewitz, if the political benefits of a war are bigger than the acceptable costs and losts, the war can be justified: the winner gets more advantage than without a war against the adversary. ${ }^{6}$ Waltz however explained that it does not matter how many members the atomic club has, initiating and fighting a war is pointless since in such a conflict there is no winner and the fighting parties may lose everything. [9] So the retaliation capability - lacking a world government - keeps the system of anarchic states under control. [11] As evidence Waltz mentions the fact that atomic powers have not waged war against each other since World War II. [9]

Kenneth Waltz took Robert Oppenheimer's (nuclear phyisicist who participated in the American atomic program) simile, according to which nuclear powers behave in the international system like two scorpions in a bottle. Both of them are able to kill the other but only at the risk of their own life. This mutual vulnerability and destructive power hinders the breakout of a general war and ensures the maintenance of peace. [12]

In contrast to Waltz, Scott D. Sagan, a liberal American theorist stands totally against the spread of nuclear weapons. It is worth observing the debate between Sagan and Waltz which has been published several times. Sagan argues that possessing a huge number of nuclear weapons can lead to the security dilemma described by Robert Jervis, an American political scientist. [13] This does not strengthen the security of the international system but may also cause serious problems. [14]

According to the analysis of the American authors, Ned Lebow and Janice Gross Stein, possessing nuclear weapons can inspire states to two kinds of behavior: it can make them self-confident and emboldened to act, however it can also encourage them to maintain peace (see: Oppenheimer's simile) The authors demonstrated their arguments with the case of the Cuban Missile Crisis in which both mechanisms affected the parties. [15]

Albert Wohlstetter (1913-1997), who worked as a mathematician at the American research institute RAND Corporation, was against the spread of nuclear weapons, too. In his view this was the problem of "N+1". "N" stands for the number of states already possessing nuclear weapons which has changed from time to time. In Wohlstetter's formula the " +1 ” means the state which wants to get into the atomic club. Examining Europe, more precisely the European countries of the Western Bloc, he explained that these states have four ways to go:

- States can utterly reject nuclear weapons, be they in the possession of the United States or any other country;

- They can make efforts to develop their own nuclear capability;

6 George Lakoff is cited by Szilágyi Ákos [10]. 
- Countries can create a nuclear force under common control;

- They also have the possibility to rely on the security guarantee of the USA.

Wohlstetter proved in his analysis - confirming Sagan's idea - that the only one rational choice for Europe can be the last alternative, any other would only weaken the Alliance. [16] Eventually NATO chose this way at the end of the 1950s.

The Alliance would have had no other option, because the Soviet political and military leaders counted on the use of tactical and strategic nuclear weapons in their military scenarios and operational planning - even if they had only a few number of nuclear weapons in the 1950s. (Graph 1.) Although the Soviet high politics utterly condemned (American) nuclear weapons, their use was considered simply illegal, contrary to international law. Nonetheless the Soviets did not explain their own developments, they justified it as an enforced move. ${ }^{7}$ Khrushchev affirmed in his statements many times that the Soviet Union will give a nuclear answer to a nuclear attack. The First Secretary of the Communist Party of the Soviet Union stated, he has no noubt that one of the two superpowers will use its atomic weapons in case it is losing in a conventional war - initiated by imperialists. [17]

The Soviet opinion always correlated with the possibilities of nuclear capability developments and with the political phraseology that denied general nuclear war. However the Soviets had just begun building their atomic arsenal, they counted on their use in operational planning. According to the conceptions at that time, the Soviet Union wanted to use conventional and nuclear forces jointly in fast offensive operations in depth, however atomic weapons would not have been deployed on the whole theater of war but only in some operational areas. The Soviet military doctrine also took into account using nuclear weapons to destroy the hinterland of the enemy, the so called "Military-Industrial-Complexes". From this time on the "doublethink" was typical for the Soviet politics, inasmuch as they denied the concept of total nuclear war on the level of high politics, they opposed the idea of the first use of atomic weapons and condemned the concept of preemptive strike and they hid their nuclear developments.

The differences between theory and practice generated famous debates in the 1950s when Herbert Dinerstein criticised the Soviet Union in his article in Foreign Affairs in January 1958. The article was disclamed by General Vladimir Kurasov in an issue of Krasnaya Zvezda in April. ${ }^{8}$

From the 1960s the Soviets started a huge nuclear development program, established strategic-level troops and in possession of nuclear capabilities they began to talk about using nuclear weapons more and more openly. In 1962 Marshal Vasily Sokolovsky (1897-1968) wrote in his book "Military Strategy" honestly about using nuclear weapons. According to Sokolovsky, who determined Soviet strategic thinking for a long time, eliminating the enemy, destroying targets in depth and disorganizing the function of the adverse country are parts of a unified war process which can not disregard nuclear weapons.

Lieutenant General Zav'yalov stated this later, noting that the appearance of nuclear weapons completely changed the principles of warfare that were known before. While the

7 According to O. V. Bogdanov, Senior Research Associate of the Institute of State and Law of the Academy of Sciences of the Soviet Union, the use of nuclear weapons is against The Hague and Geneva Conventions and violates the Martens-Clause. This concerned weapons of a tactical nature too, because they are just as illegal as strategic nuclear weapons. See more: [17].

8 The American Edward L. Warner III. also refers to the debate. See more: [18]. 
destructive power of weapons had increased significantly and they could be deployed over hundreds of kilometers at any time, the actions of troops and their protection on the battlefield remained unchanged. So the distinction of strategy, operational art and tactics became pointless, and the concept of offense and defence is not compatible with the old perceptions referring to past wars. [19] [20]

The introduction of nuclear weapons made the Soviet mlitary leadership reconsider the key subject of the initial phase of a future war, the deployed forces and their concentration as well. Maneuvering got a primary role because it could decrease the chance of using nuclear weapons since this way the troops were less likely targeted. Force protection against NBC weapons came quickly into focus. [21]

At one point however both superpowers agreed: none of them was interested in the spread of nuclear weapons and a breakout of a general nuclear war. Aleksandr Zinoviev, a Russian geopolitical scientist wrote in his book "Homo Sovieticus" the following "about the next war":

"After the First World War it looked as though the next one would be chemical and that all humanity would perish from poison gases. But it wasn't a chemical war. And humanity didn't perish: it almost doubled itself. Now it seems that the Third World War will be nuclear and that all humanity will perish from nuclear bombs and radiation. But it won't be a nuclear war. And humanity will remain intact. And most likely it will multiply even more. Why won't the war be nuclear? Because it isn't to our advantage that it should be nuclear. And so we won't allow it to be nuclear." [22]

\section{NATO’s First Strategic Concepts}

In 1949, when the North-Atlantic Treaty Organization was established, the primary goal was to create an overall strategic concept which might be a basis for defence planning of the new Alliance. [23]

The Soviet Union used to be an outstanding danger in European general opinion and also for politicians before the end of World War II. The superpower, as a victorious nation, possessed large armed forces and technology, whereas the relations between the East and the West seemed to be more and tenser.

“...Meanwhile what is to happen about Russia? [...] I feel deep anxiety because of [...] their power to maintain very large armies in the field for a long time. What will be the position in a year or two, when the British and American Armies have melted and the French has not yet been formed on any major scale, when we may have a handful of divisions mostly French and when Russia may choose to keep two or three hundred on active service?” [24: 47-48]

Therefore, all the efforts of Western Europe were made to obtain the USA's security guarantee which was embodied at this time by its nuclear monopoly. Washington - learning from the consequences of its isolation policy after World War I - did not leave Europe alone and became an important element in realizing the so called containment-policy. ${ }^{9}$

"Deterrence is the art of producing in the mind of the enemy the fear to attack." [26]

9 The expression was first used by George F. Kennan in his famous “Long Telegram” in 1946. The former American diplomat accredited to the Soviet Union explained his point of view under the pseudonym "Mr X" in his article "The sources of Soviet Conduct" published in Foreign Affairs. The United States was realizing this theory through establishing a system of alliances (Organization of American States - OAS; Australia, New Zealand, United States Security Treaty - ANZUS; Southeast Asia Treaty Organization - SEATO; Central Treaty Organization - CENTO). See more: [25]. 
In the first NATO strategic document [27] the parties emphasized that the Alliance's purpose is to create an effective deterrent capability. Furthermore, should the deterrence fail and war occurs, the member states are going to defend the North-Atlantic area and restore NATO's security. In this document, in 1949, it was written that the Alliance needs to be able to "insure the ability to carry out strategic bombing including the prompt delivery of the atomic bomb”. In 1952 this document was modified. In the new strategic concept [28] - because of Danish concerns - it was stated that NATO should "insure the ability to carry out strategic bombing promptly by all means possible with all types of weapons, without exception”. However, the parties emphasized that this change was made only in phrasing not in the position. [23]

Thus, it can be easily noticed that nuclear weapons were already very important factors in the early period of NATO - and also of the Cold Wars. To achieve the goals mentioned above a very loose and primitive structure was established. Certain bodies met irregularly, the main part of planning fell on the five regional planning groups. ${ }^{10}$

The Korean War induced significant changes in NATO, the defence of the allies came to the front again. Lord Ismay, NATO's first secretary general raised the question: How could the Alliance defend itself against similar agression? [7] Athough in Korea there were not any atomic weapons used thanks to the wise decision of the fighting parties, ${ }^{11}$ the West was forced to re-think its future prospects. So Henry Kissinger was entitled to refer to this period as a dilemma of containment. [29]

\section{The New Look of the 1950s}

In the 1950s a new approach was unfolding in the Alliance. The defence budget of the member states obviously could not increase any more. [30] European allies could not achieve American expectations, [31] but not even the USA could maintain its military burdens at the same level as before. On the other hand, the Alliance had to take into account that the Soviet Union was superior to NATO in numbers of conventional forces - just like at the end of World War II, but since then the difference has became bigger and bigger because of the armed forces' different concepts of disarmament. [32] [33]

Combining maximum efficiency of the armed forces and maximum economy of manpower, money and materials was one of the most important elements in NATO's strategy in the 1950s, too. However, this evoked a totally different answer, another sort of pressure of co-operation like there it is nowadays among NATO members under the "Smart Defence" concept.

The solution in the 1950s was - instead of increasing conventional forces - to urge the development of military technology and gain technological (nuclear) superiority. In 1952 the British Government suggested that the confrontation with the Eastern Bloc needs to be built on nuclear deterrence. ${ }^{12}$ Then in 1954 US Secretary of State, John Foster Dulles said that the USA has to define its political orientation and efforts for the long term. The most important

10 The five regional planning groups were the following: Northern Europe, Western Europe, Sothern Europe/ Western Mediterranian, United States/Canada, and the North Atlantic Ocean.

11 Some of the military leaders supported the proposal for a nuclear war - in the Korean War General MacArthur made such a proposal to the American President.

12 In 1951 Churchill as a returning Prime Minister decreed an immediate defence review and in October 1952 the UK tested its first nuclear bombs. See more: [2]. 
decision is to base the country's defence on a great deterrent capacity which can be deployed at any place and anytime. [34] This speech is often referred to as the base of "massive retaliation” theory, even if Dulles’ original idea is not the same as the later introduced massive retaliation policy. The basic principle of the strategic re-orientation should have been - according to Dulles - the free choice of response to agression without any restriction.

In 1952 Matthew B. Ridgeway (GEN) replaced Dwight D. Eisenhower (GOA) as the Supreme Allied Commander Europe (SACEUR). He conducted a study about the impact of a possible use of NATO's nuclear weapons on the Alliance's forces. Ridgeway explicated that NATO could prevail in the case of nuclear war insofar as it is able to compensate its losses by ground forces (so their development is mandatory) and hereby NATO can exploit the advantages given by the unfolding campaign. In his opinion to achieve these goals SACEUR needs to have predelegated authority to decide about using nuclear weapons. ${ }^{13}$

Meanwhile the United States was dinamically developing its tactical nuclear weapons. There were many political-military debates, which raised important questions like does it make sense to use such weapons when they can only gain temporary advantages but they can easily lead to general nuclear war. Does their deployment in Europe mean benefits as great as damages it can cause in the European states and societies, and when the military task - demand of early response - stands in contradiction to politics which tends to wait for developments. In the meantime the first tactical nuclear weapons arrived on the continent. [7]

In 1954 the NATO Military Committee submitted its report to the North-Atlantic Council (NAC) in which the creators concretely count on the use of nuclear weapons in a future conflict. However, the chiefs of staff expressed their concern about the devastating effects of atomic weapons and the difficulty of defence against them, which creates problems not only of military but political, economic, social and a psychological nature as well. Nevertheless they stated that initiating a general nuclear war would be contradictory with the Alliance's guiding principles so it can come to that only if the Soviets attack the Alliance intentionally or because of miscalculation. The Military Committee also saw it as possible that the Soviet Union does not plan using nuclear weapons against Western Europe hoping that neither does the Alliance. Still, in response to such an attack NATO can give one and only one answer, to deploy nuclear weapons on a strategic or tactical level. [35] It was only a step away from introduction of the principle of massive retaliation into NATO's strategy.

In the midst of political and military debates the development, production and accumulation of nuclear weapons at an increased rate had begun. (Table 1. and Graph 1.) At the end of the 1940s the United States had less than 200 atomic weapons but in the next five years this number had a tenfold increase. Furthermore, at the end of the 1950s this number achieved the order of magnitude of 10,000. At that time the Soviet Union had slightly more than 1,000 atomic weapons. All these made the strategy of massive retaliation well-founded in the Alliance.

13 These aspects were contradictory to NATO's goals at the moment, so General Ridgway was removed from his office. His successor, General Alfred Gruenther began a new examination of these questions. As a result he submitted a "new approach"to the political decision makers which based the Alliance’s defence decisively on nuclear weapons. 
Table 1. Global nuclear weapons inventories 1945-1960.

Source: Bulletin of the Atomic Scientists [36]

\begin{tabular}{|c|c|c|c|c|}
\hline Year & USA & Soviet Union & United Kingdom & Total \\
\hline 1945 & 2 & 0 & 0 & 2 \\
\hline 1946 & 9 & 0 & 0 & 9 \\
\hline 1947 & 13 & 0 & 0 & 13 \\
\hline 1948 & 50 & 0 & 0 & 50 \\
\hline 1949 & 170 & 1 & 0 & 171 \\
\hline 1950 & 299 & 5 & 0 & 304 \\
\hline 1951 & 438 & 25 & 0 & 463 \\
\hline 1952 & 841 & 50 & 0 & 891 \\
\hline 1953 & 1169 & 120 & 1 & 1290 \\
\hline 1954 & 1703 & 150 & 7 & 1860 \\
\hline 1955 & 2422 & 200 & 14 & 2636 \\
\hline 1956 & 3692 & 426 & 21 & 4139 \\
\hline 1957 & 5543 & 660 & 28 & 6231 \\
\hline 1958 & 7345 & 869 & 31 & 8245 \\
\hline 1959 & 12298 & 1060 & 35 & 13393 \\
\hline 1960 & 18638 & 1605 & 42 & 20285 \\
\hline
\end{tabular}

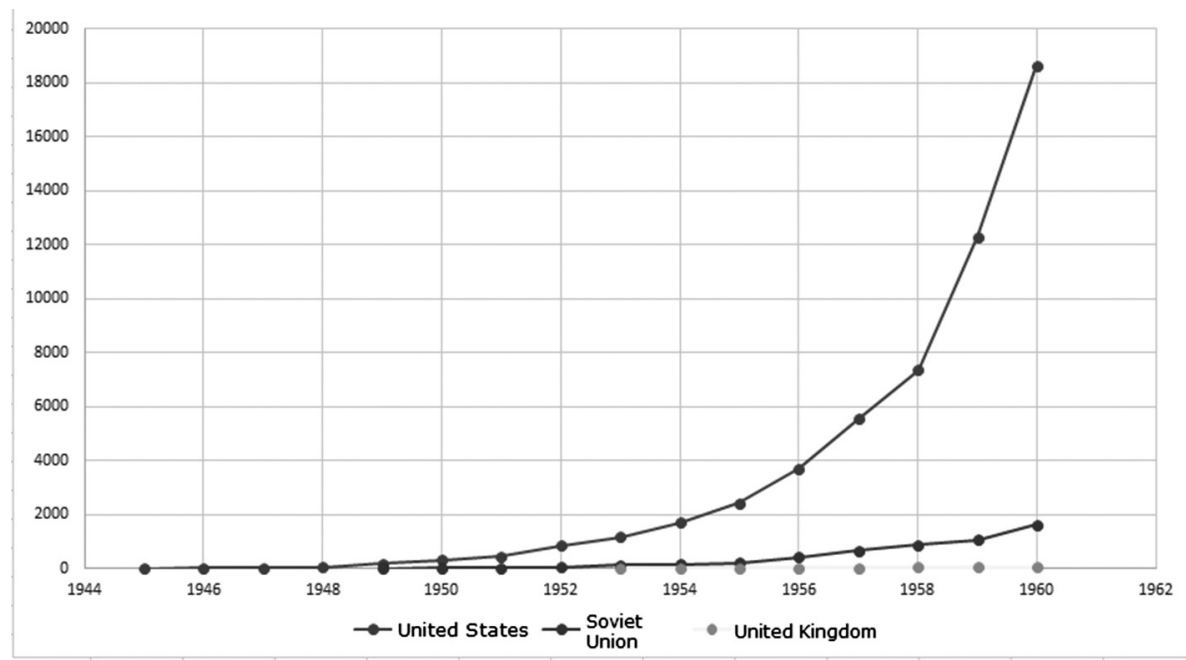

Graph 1. Global nuclear weapons inventories 1945-1960. (Edited by Kiss Petra) [36]

\section{The Strategy of Massive Retaliation}

The NAC approved the document MC 14/2 [37] in May 1957 which contained the new Overall Strategic Concept of the Alliance. The paragraph which targets the efficiency and economic effectiveness as a guiding principle for defence is to be highlighted. In terms of future war the strategy reflects internationally accepted elements. The document declares that nuclear weapons drastically change the conditions of modern warfare so the experiences 
and lessons learned from previous armed conflicts can not be applied. As NATO's primary goal the document states NATO has to avert general (nuclear) war. If a war is forced upon the Alliance it has to possess the means and capabilities to defend its population, and the territory covered by the North Atlantic Treaty. In case of a general war the strategy differenciates two main phases:

- The first phase includes only the first days of war (a 30-day-period maximum), which can be characterized by intensive nuclear exchanges.

- The second phase takes up more time, during which the armed forces have to be re-organized, they need rehabilitation and their supply is also to be ensured. ${ }^{14}$

It is almost a euphemism that in such a strategic document the consequencies of nuclear strikes are only described as a situation when forces can not be mobilized, military tasks can not be fulfilled and the lines of communication and logistical support need to be reconstructed. In the second phase however planners took into account conventional warfare when allied forces can exploit the advantages gained in the first phase and win. NATO did not take into account the further (long term) impacts of nuclear attacks..$^{15}$

Nevertheless, a kind of flexibility can already be noticed in this strategic concept, insofar as the strategy prescribes that the member states have to be prepared in case of infiltration, incursions or hostile local actions "to deal immediately with such situations without necessarily having recourse to nuclear weapons”. [37]

Through this decision NATO member states became - basing their strategy on nuclear weapons ${ }^{16}$ - totally dependent upon the United States..$^{17}$ Therefore Allies saw it as necessary to take part in decision making in connection with their defence even if they do not have nuclear weapons. According to President Eisenhower there were two options for that. One solution could have been the USA's offer for NATO to provide nuclear weapons. These weapons would have been in peacetime under American control and command, but in case of war they would have been under NATO's control - in accordance with plans of the SACEUR. In a second scenario the USA would have deployed intermediate-range ballistic missiles (IRBMs) in Europe. ${ }^{18}$

Meanwhile the Soviet Union had completed serious technical developments as well. The most important one was probably launching into space the first artificial satellite, Sputnik I in 1957, which undermined the basic idea of massive retaliation, namely the belief in the victory of Western technology over the superiority in manpower of the Soviet Union. Moreover, at the end of the 1950s the Soviets had had already intermediate-range missiles targeting Europe.

A tremendous arms race had just started between the two superpowers in which Europe wanted to participate anyway. Especially the mutual fear from surprise attacks made this rivalry uncontrollable and which could have increased the chance of an attack: mutual trust

14 There are similar ideas in Albert Wohlstetter's concepts about first strike and second strike. See more: [38].

15 It is worthy of note, because NATO's member states, defence ministries just like research institutes and other nongovernmental bodies were permanently examining the consequencies of a nuclear war. See more: [3].

16 This did not mean that conventional forces have to be disarmed, particularly because certain elements of "flexible response" (as mentioned before) made it necessary to maintain them to some extent.

17 Both the United Kingdom and France lost their positions as great powers, therefore status politics and getting the atomic secret were of great importance. However their nuclear weapons could not be significant enough to replace the American nuclear security guarantee for Europe. See more: [39].

18 In practice this would have been the extension of a previous British-American agreement with the same subject to the other European allies. 
was lacking, the parties did not know the intentions of the other and they fell into the trap which was described by T. C. Shelling. ${ }^{19}$

As a short term solution the United States offered the Alliance five newly developed Washington class nuclear-powered ballistic missile submarines with Polaris A-1 missiles to counteract the threat of Soviet missiles. In the long run maintaining a nuclear-powered ballistic missile submarine could have been the answer according to the American conception - in common ownership, with joint personnel and common funding. ${ }^{20}$ The so called "Multilateral (Nuclear) Force” (MLF) concept could have given a chance for European allies to participate actively in NATO's nuclear mission. In the promising early years of the European integration the USA was ready to hand over the control of MLF to a new European authority in case of successful integration. [7]

However, the strategic thinking of the USA was altered at the end of the 1950s, NATO closed this decade focusing on the strategy of massive retaliation.

\section{Conclusions}

Nowadays the importance of factors and processes which were essential in the first ten years of NATO seem to be decreased. Nonetheless, if we examine the relevant, influencing factors and the answers in this period more carefully we can observe some really interesting parallelisms.

The unbalanced burden sharing within the Alliance is not a new question, it has been a problem since the first years. The difference is that in the 1950s the United States was able and willing to help its allies financially. Economic and financial problems, however, made the current political and military leaders think over their policy as much as they did it during the past few years as the result of the global financial crisis. The solution - may it be utterly distinct at that time compared with our days - evolved along similar lines as we saw in the decisions of the Wales Summit.

Member states could not maintain as large armed forces as they did during the war. Reduction in manpower and transformations happened which caused damages in the capabilities of forces. But the credibility of the Alliance could have been at risk if it could not ensure its own security and the necessary capabilities. Thus, the answer laid in nuclear technology developments, since earlier conventional forces in great strength could not be maintained. To achieve and retain technical superiority huge resources were needed. As a consequence the necessity of multinational funding and the idea of development and maintenance of joint capabilities were conceived already at the beginning of the 1960s.

Anyhow, the above examined time period reflects today's main questions - even if there are smaller differences. At that time the shadows of a nuclear war, nowadays the emerging

19 T. C. Shelling (USA) was motivated in his game theory research by the arms race evolving in the 1950s. He pointed out that under the given conditions of a nuclear age, a surprise attack can give such a big advantage to one party preparing for a nuclear war that it became worth attacking first. According to this, the one party - believing that the other one is preparing for a surprise attack - could have felt encoureged to increase its armament and initiate an attack against the other with justification. Considering that at the end a successful nuclear surprise attack gives far fewer advantages than avoiding war there is no way to justify such an attack. See more: [40].

20 In this concept is easy to recognize today's idea of ballistic missile defence, AGS and other great NATO projects. 
security risks and threats has determined the processes. We are confident that NATO will be able to adapt to the changing security environment and new conditions (the Ukranian crisis, emerging of ISIS) as it did in the 1950s as well as in the recent past. As a last remark let us cite Professor Megginson's words, who served in the American air force during World War II:

"It is not the strongest of the species that survives, nor the most intelligent that survives. It is the one that is most adaptable to change." [41]

\section{References}

[1] KECSKEMETI, P.: Strategic surrender. The politics of victory and defeat. Santa Monica: RAND Corporation, 1957. www.rand.org/content/dam/rand/pubs/reports/2007/R308.pdf (downloaded: 2309 2013)

[2] FREEDMAN, L.: The first two generations of nuclear strategists. In. PARET, P. (Ed.), Makers of modern strategy from Machiavelli to the nuclear age, Princeton: Princeton University Press, 1986. DOI: https://doi.org/10.1515/9781400835461-027

[3] MILLER, D.: The Cold War. A military history. New York: St Martin’s Press, 1998.

[4] Draft Report by the National Security Council on United States Policy on Atomic Warfare. NSC 30, September 10, 1948. FRUS, I 2 (1976), 624-628. http://images.lib1rary.wisc.edu/ FRUS/EFacs/1948v01p2/reference/frus.frus1948v01p2.i0007.pdf (downloaded: 2712 2013)

[5] Baruch Plan, Presented to the United Nations Atomic Energy Commission 1461946. www.atomicarchive.com/Docs/Deterrence/BaruchPlan.shtml (downloaded: 2809 2013)

[6] PATIJN, C. J.: Az atomfegyverek problémája. Jöjjetek, 11 7-8 (1958).

[7] WHEELER, M. O.: NATO nuclear strategy, 1949-90. In. SCHMIDT, G. (Ed.), A history of NATO - The first fifty years, III. New York: Palgrave, 2001.

[8] BBC Fact File: Hiroshima and Nagasaki. BBC News www.bbc.co.uk/history/ ww2peopleswar/timeline/factfiles/nonflash/a6652262.shtml (downloaded: 81 2013)

[9] WALTZ, K. N.: The spread of nuclear weapons: More may be better. Adelphi Papers, 171 (1981). https://woc.uc.pt/feuc/course/MRI/2007-2008/Kenneth\%20Waltz\%20-\%20more\%20 is\%20better.pdf (downloaded: 1111 2013) https://doi.org/10.1080/05679328108457394

[10] SZILÁGYI Á.: A háború privatizálása. In. GOMBÁR, Cs., VOLOSIN H. (Eds.), Képtelen háború, Budapest: Korridor, Helikon, 2004.

[11] SAGAN, S. D., WALTZ, K. N.: Is nuclear zero the best option? The National Interest, 09-10 2013. http://nationalinterest.org/greatdebate/yes-3950?page=1 (downloaded: 1211 2013)

[12] JOHNSON, G.: 2013. What made him tick. 'Robert Oppenheimer', a Biography by Ray Monk. The New York Times. Sunday Book Review, June 28, 2013. www.nytimes. com/2013/06/30/books/review/robert-oppenheimer-a-biography-by-ray-monk. html?pagewanted=all\&_r=0 (downloaded: 1411 2013)

[13] JERVIS, R.: Cooperation under security dilemma. World Politics, 302 (1978), 167-214. www.sscnet.ucla.edu/polisci/faculty/trachtenberg/guide/jervissecdil.pdf (downloaded: 1411 2013) https://doi.org/10.2307/2009958

[14] SAGAN, S. D.: Why do states build nuclear weapons? In. HUGHES, C. W., MENG, L. Y. (Eds.), Security Studies, New York: Routledge, 2011, 222-229.

[15] LEBOW, N. GROSS, S. J.: Nuclear deterrence. In. HUGHES, C. W., MENG, L. Y. (Eds.), Security Studies, New York: Routledge, 2011, 195-202. 
[16] WOHLSTETTER, A.: Nuclear Sharing: NATO and the N+1 Country. Foreign Affairs, 04 1961. www.foreignaffairs.com/articles/71616/albert-wohlstetter/nuclear-sharing-natoand-the-n1-country (downloaded: 1211 2013) https://doi.org/10.1080/00396336108440265

[17] MAGGS, P. B.: The Soviet viewpoint on nuclear weapons in international law. http://scholarship.law.duke.edu/cgi/viewcontent.cgi?article=3034\&context=lcp (downloaded: 1011 2013)

[18] WARNER III, E. L.: Soviets Concepts and Capabilities for Limited Nuclear War. What we know and how we know it. Santa Monica: The RAND Corporation, AD-A208308. 02 1989. 9. www.google.hu/url?sa=t\&rct=j\&q=\&esrc=s\&frm=1\&source=web\&cd=18\&ved= 0CFsQFjAHOAo\&url=http\%3A\%2F\%2Fwww.dtic.mil\%2Fcgi-bin\%2FGetTRDoc\%3FA D\%3DADA208308\&ei=4PORUvHPBIWStAaM-IDoAQ\&usg=AFQjCNGbH4-19mEBIL 7tVPCtT9Fw_2KniA\&sig2=fwZJgL2NGLc_e4l7ImjqzA\&bvm=bv.56988011,bs.1,d.bGE (downloaded: 2311 2013)

[19] CHEREDNICHENKO, M.: Some features of modern military art. In. ORENSTEIN, H. S. (Ed.), The evolution of Soviet operational art, 1927-1991, Vol. II, London: Frank Cass \& Co Ltd., 1995, 125-137.

[20] ZAV'YALOV, I. G.: The evolution in the correlation of strategy, operational art and tactics. In. ORENSTEIN, H. S. (Ed.), The evolution of Soviet operational art, 1927-1991, Vol. II, London: Frank Cass \& Co Ltd., 1995, 138-148.

[21] GLANTZ, D. M.: The heyday of operational art 1970-86. In. ORENSTEIN, H. S. (Ed.), The evolution of Soviet operational art, 1927-1991, Vol. II, London: Frank Cass \& Co Ltd., 1995, 121-124.

[22] ZINOVJEV, A.: Homo Sovieticus. 1982. OSZTOVICS Á. (ford.), Budapest: Masszi Kiadó, 2001.

[23] PEDLOW, G. W.: The evolution of NATO strategy. In. NATO strategy documents 1949-1969, 1997. www.nato.int/archives/strategy.htm (downloaded: 2809 2013)

[24] FISCHER, F.: A megosztott világ. Budapest: Ikva Kiadó, 1992.

[25] HAJMA, L.: Stratégiai célok - Katonai doktrínák. Budapest: Kossuth Könyvkiadó, 1982.

[26] LONG, A.: Deterrence. From cold war to long war. Santa Monica: RAND Corporation, 2008. www.rand.org/content/dam/rand/pubs/monographs/2008/RAND_MG636.pdf (downloaded: 2809 2013)

[27] DC 6/1. The Strategic Concept for the Defence of the North-Atlantic Area. 1121949.

[28] MC 3/5. The Strategic Concept for the Defence of the North-Atlantic Area. 3121952.

[29] KISSINGER, H: Diplomácia. Budapest: Panem, 2008.

[30] Directive to the NATO Military Authorities from the North Atlantic Council. C-M (56)138 Final. Paris, 1956. www.nato.int/docu/stratdoc/eng/a561213a.pdf (downloaded: 2809 2013)

[31] HAFTENDORN, H.: Németország csatlakozása a NATO-hoz: 50 évvel később. NATO Review, 2005. www.nato.int/docu/review/2005/issue2/hungarian/history.html (downloaded: 2809 2013)

[32] MC 14. Strategic Guidance for the North Atlantic Regional Planning. 2831950.

[33] BIZTINGER, R. A.: Assessing the conventional balance in Europe, 1945-1975. Santa Monica: RAND Corporation, 1989. www.rand.org/content/dam/rand/pubs/notes/2007/ N2859.pdf (downloaded: 0710 2013) 
[34] DULLES, J. F.: The evolution of foreign policy. (Dulles' speech, Council on Foreign Relations 12 January, 1954), Air Force Magazine, 1954. www.airforcemag.com/ MagazineArchive/Documents/2013/September\%202013/0913keeperfull.pdf (downloaded: 2309 2013)

[35] MC 48. A report by the Military Comittee on the most effective pattern of NATO military strenght for the next few years. 22111954.

[36] Bulletin of the Atomic Scientists. http://bos.sagepub.com/content/66/4/77/T2.expansion.html (downloaded: 2510 2013)

[37] MC 14/2. Overall Strategic Concept for the Defence of the North Atlantic Treaty Organization Area. 2351957.

[38] WOHLSTETTER, A.: The delicate balance of terror. Santa Monica: RAND Corporation, 1958. www.rand.org/about/history/wohlstetter/P1472/P1472.html (downloaded: 3009 2013)

[39] KRIEGLER, W.: NATO and nuclear weapons. In. SCHMIDT, G. (Ed.), A history of NATO The first fifty years, Vol. III, New York City: Palgrave, 2001.

[40] SCHELLING, T. C.: The reciprocal fear of surprise attack. Santa Monica: RAND Corporation, 1958. http://130.154.3.14/content/dam/rand/pubs/papers/2007/P1342.pdf (downloaded: 2909 2013)

[41] MEGGINSON, L. C.: Lessons from Europe for American Business. Southwestern Social Science Quarterly, 441 (1963), 4. 